\title{
LAND USE LIMITATIONS: ENVIRONMENTAL AND SOCIOECONOMIC IMPACTS
}

\author{
Petrakovska Olga, Mykhalova Mariia \\ Kyiv National University of Construction and Architecture, Ukraine
}

\begin{abstract}
Land use regulation is one of the most important state tasks and is aimed to ensuring the sustainable development of settlements. One of the mechanisms to solve this task is land use limitations establishment by restricted the possibility to carry out some activities, on certain territories or separate land plots, which would lead to negative ecological and social consequences. Such activity is becoming more and more urgent in the face of increasing ecological problems.

Land use limitations could be considering in different areas. On one hand, the feasibility of land use is governing by the methods of spatial planning, based on natural and anthropogenic conditions. On the other hand, land use limitations are the result of location of object is which could be either source of negative influence or the object is requiring being protected (mode-forming objects).

The aim of the article is to determine the impact of land use limitations on the various components of society, taking into account the environmental, economic and social components of sustainable development. Environmental and socioeconomic impact of land use limitations formation on the example of limitations caused by the activity of a mode-forming object are described in the study. The results of the study illustrate that the establishment of limitations on the land use can solve mainly environmental and social problems.
\end{abstract}

Key words: land use limitations impact, land use regulations, mode-forming objects.

\section{Introduction}

There is a need to transform the approaches and mechanisms available in Ukraine to regulate land use within the current conditions of integration processes activated at the end of the XX century.

In Ukraine, the experience of land use management under different forms of ownership began to be acquired only in the beginning of the XXI century. The methods and means of regulating decisionmaking issues should, first and foremost, work to improve the living conditions of the population; preserve the ecological stability of the territories; increase the value and cost of land, as well as enhance their investment attractiveness while ensuring equality of rights regardless of ownership.

Today the decision-making to ensure a balanced, sustainable and integrated development of territories is a complex task that involves many challenges and participation of a large number of entities (authorities, landowners, users, businesses).

Recently, the land use limitations mechanism has become of great importance as a regulator of providing favorable living conditions for the population and development of territories. One of the common application areas of this mechanism is a restriction of certain activity types in territories or particular land plots that lead to adverse effects. The methods and mechanisms of land use limitations existing in Ukraine are not always open, understandable and do not take into account all components of sustainable development.

\section{Methodology of research and materials}

The aim of the article is to determine the impact of land use limitations on the various aspects of society's life, taking into account the environmental, economic and social components of sustainable development.

The following tasks are aimed to achieve this goal:

1.To analyze the mode-forming objects, the functioning of which requires the organization of zones, within whose boundaries there are limitations on the use of land.

2.To perform the analysis of land use limitations.

2. To structure the land use limitations depending on various features.

3. To analyze the land use limitations caused by the activity of mode-forming object.

Research was based on the analysis of legal and regulatory acts, scientific literature and the analytical materials. The main focus was done on environmental and social impact. The theoretical debatable research results were surveyed on the examples of mode-forming objects in Ukraine. The results were 
carried out used methods of collection, systematization, processing, logical analysis and generalization. The analysis and synthesis, comparison and system methods also were applied during this work.

\section{Discussions and results}

\section{Limitations as mechanism of land use regulations}

Land use regulations - ordinances of government created to ensure private and public use of land are aligned with policy priorities and standards. Land use regulations have increased substantially over the decades. Land-use regulations are an umbrella term for rules that govern land development. And limitations are an important mechanism of land-use regulations. Land-use regulations control the land development through land use limitations formation in order to achieve various safety, environmental stability, and social fairness (Land Use Restrictions as Barriers to Entry, 2008).

Land use limitation is a set of actions used to establish the optimal mode of land and land plot use. The need to set land use limitations is due to the need to preserve natural resources (agricultural, water, forest, mineral); protect historical and cultural heritage; ensure environmental protection (air, water, soil); ensure safety of life of the population; improve conditions of social life of the population. In fact, the land use limitation is a state interference with property rights. But it is justified in terms of guaranteeing free access to natural resources, social goods and aimed at protecting the common public interests and the third party rights (Petrakovska, 2010, Garrett Power, 2013)

The need to set land use limitations depends on natural resource potential, climatic conditions and ecological status.

\section{Types of land use limitations}

The study of statutory land use limitations has allowed carrying out their structuring by using different signs.

Almost all existing land use limitations can be combined into two aggregate groups:

1. Limitations, whose size and mode of use are clearly defined by the legislative and regulatory documents. That is, they are known in advance.

As an example, they include limitations imposed by different types of engineering communications.

2. Limitations governed by different types of spatial plans and social programs.

Depending on the object subject to the limitation, the limitations can be divided into 3 groups:

1. limitations that apply to a certain territory;

2. limitations that apply exclusively to land plot;

3. limitations that apply in both cases.

As a result of the analysis of the regulatory framework (Закон України «Про землеустрій», 2003, Закон України «Про регулювання містобудівної діяльності», 2011) was defined one more sign the object features that cause limitations,

Depending on this, land use limitations may be as follows:

1. Limitations caused by the activity of a mode-forming object as a source of negative impact on the environment;

2. Limitations caused by the need to preserve existing natural resources as a whole (nature reserved fund objects);

3. Limitations caused by the need to preserve existing anthropogenic environment (cultural heritage objects).

\section{Impact of land use limitations on the various components of society's life}

The impact of land use limitations on the various components of society's life was analyzed taking into account the components of sustainable development of the territories: environmental, economic and social (Petrakovska, Mykhalova, 2018).

Decion makers increasingly accept that social impacts need to be considered along with environmental impacts because (Barrow 2002, Burdge, 1990):

- They are often closely interrelated.

- It is a wise response to the growing dremand for "social responsibility".

- It can improve environmental management and the quest for sustainable development.

Impact on nature and environment (level of air, water basin, soil pollution, noise and vibration levels, chemical pollution, etc.) was taken into account when assessing the environmental impact. 
Cultural (cultures of growing cities and their surroundings, cultural heritage, accessibility to cultural services) and health (psycho-physical health, impacts of traffic projects on health and living conditions, social health) impacts were taken into account when assessing the impact on social status.

Changes in the value of land and land plots were taken into account when assessing the impact on economic situation.

The impact of land use limitations can be assessed from the point of view of the extent of its spread. For example, groups of administrative-territorial units, separate administrative-territorial units, a group of land plots or a separate land plot. Depending on the importance of land use limitations and the extent of its spread, the impact may be local, regional, national and global. As a rule, scientists say that all impacts should be considered from local to global (Dietz, 1987).

The article analyzes the impact of land use limitations formation on the example of limitations caused by the activity of a mode-forming object on local level. According to the current legislation of Ukraine (Закон України «Про державний земельний кадастр», 2011), a mode-forming object is an object of natural or artificial origin (lake, river, forest, pipeline, energy, cultural heritage, military object etc.) under which and/or around which the land use limitations are established in accordance with the legislation in connection with its natural or acquired properties. The study revealed a significant difference between mode-forming objects. There are objects being mode-forming in essence and objects that become mode-forming only after a correspondent official status is established. The first ones include industrial objects, engineering and transport infrastructure objects, water sources, water bodies, etc.. In the second case - objects that require special protection, such as nature reserves, objects of historical heritage, health resort, etc. They legislatively establish the corresponding status, which determines the degree of necessary protection.

There are four main types of zones in Ukraine that are subject to land use limitatins: protection zones, sanitary control areas, sanitary security zones and special use areas (Земельний Кодекс України, 2001, Trevogo, Ryabchiy, M Tregub, Yu Tregub, 2019).

Protection zones are the zones established for the purpose of protecting mode-forming objects from adverse anthropogenic influences. (Земельний Кодекс України, 2001).

Sanitary control zones are the area where a special sanitary-epidemiological mode is introduced in order to prevent negative influence from outside on the protected object (for example sources of centralized drinking water supply facilities) (Земельний Кодекс України, 2001).

Sanitary security zones are the zones established around potential sources of various types of pollution in order to reduce or exclude negative impact on adjacent territories (Земельний Кодекс України, 2001).

A special group consists of special use areas that are formed around defense and military objects to protect the population, businesses and environment from the effects of emergencies. This type of restriction is not analyzed within the scope of this study.

Exploring the land use limitations impact, the following meaning was put into definitions of environmental and social effects.

Environmental impact reflects the direct effect of land use activities and their limitations on the components of the environment. Social impact is the effect on people and communities that happens as a result of active and passive land use.

Environmental and social impact studies show that both direct and indirect impacts are observed (Wathern, 1988, Sairinen, 2004). This article is focused on direct influence.

The results of analysis of environmental and social impact of land use limitations are shown in Table 1. The table shows examples of zones that are installed around mode-forming objects. There are also other types of land use limitations, such as protection zone around the objects of communication, objects of hydrometeorological activity, etc

The analysis results show that most of the land use limitations have a positive environmental impact and improve the quality of environmental conditions. Limitations on the use of land are strictly regulated by law and are aimed at complying with environmental and social standards. It is important to note that the social effect is closely related with the ecological one and is expressed in improving the comfortable living conditions of the population by preventing the negative consequences of the activity of the modeforming object or maintaining their integrity. As well the social effect of the establishment of land use limitations is expressed by the formation of mass consciousness, which characterizes the attitude of people to socially significant events and current issues of public life. 
Table 1

Environmental and social impact of land use limitations around mode-forming objects

\begin{tabular}{|c|c|c|c|c|}
\hline $\begin{array}{c}\text { Limitations of land } \\
\text { use }\end{array}$ & \multicolumn{2}{|c|}{ Mode-forming object } & Environmental impact & Social impact \\
\hline \multicolumn{5}{|c|}{ 1. Limitations arising from the granting of object official status } \\
\hline \multirow{3}{*}{ Protection zone } & \multicolumn{2}{|c|}{$\begin{array}{l}\text { objects of the nature } \\
\text { reserve fund* }\end{array}$} & $\begin{array}{l}\text { preservation of protected } \\
\text { object which have } \\
\text { significant importance on } \\
\text { ecological conditions }\end{array}$ & $\begin{array}{l}\text { preserving integrity of object } \\
\text { to ensure conditions of social } \\
\text { life (rest, studying, recovering, } \\
\text { communication) }\end{array}$ \\
\hline & \multirow[t]{2}{*}{$\begin{array}{l}\text { objects of } \\
\text { cultural } \\
\text { heritage* }\end{array}$} & natural & $\begin{array}{l}\text { preservation of protected } \\
\text { object which have } \\
\text { significant importance on } \\
\text { ecological conditions }\end{array}$ & \multirow{2}{*}{$\begin{array}{l}\text { preserving integrity of object } \\
\text { to ensure conditions of social } \\
\text { life (rest, studying, recovering, } \\
\text { communication) and historical } \\
\text { heritage for future generations }\end{array}$} \\
\hline & & artificial & $\begin{array}{l}\text { to provide historical value, } \\
\text { preservation and integrity } \\
\text { of protected object }\end{array}$ & \\
\hline Sanitary control zone & \multicolumn{2}{|c|}{ health resorts } & $\begin{array}{l}\text { preservation of protected } \\
\text { object which have } \\
\text { significant importance on } \\
\text { ecological conditions }\end{array}$ & $\begin{array}{l}\text { preserving integrity of object } \\
\text { to ensure conditions of social } \\
\text { life (rest, recovering, } \\
\text { communication) }\end{array}$ \\
\hline \multicolumn{5}{|c|}{ 2. Limitations around objects of transport and engineering infrastructure } \\
\hline \multicolumn{5}{|c|}{ 2.1 Objects of transport infrastructure (roads, transport interchanges, railways and so on) } \\
\hline Protection zone & \multicolumn{2}{|c|}{$\begin{array}{l}\text { objects of transport } \\
\text { infrastructure }\end{array}$} & $\begin{array}{l}\text { reduction of environmental } \\
\text { pollution (air, water, soil } \\
\text { pollution, noise and } \\
\text { vibration levels, chemical } \\
\text { pollution, etc) caused by } \\
\text { the object }\end{array}$ & $\begin{array}{l}\text { improving the living comfort } \\
\text { conditions of the population }\end{array}$ \\
\hline \multicolumn{5}{|c|}{ 2.2 Objects of engineering infrastructure (water supply objects, sewage systems etc.) } \\
\hline Protection zone & \multicolumn{2}{|c|}{$\begin{array}{l}\text { object of heating } \\
\text { system }\end{array}$} & $\begin{array}{l}\text { preservation of protected } \\
\text { object }\end{array}$ & $\begin{array}{l}\text { improving the living comfort } \\
\text { conditions of the population }\end{array}$ \\
\hline $\begin{array}{l}\text { Sanitary security } \\
\text { zone }\end{array}$ & \multicolumn{2}{|c|}{ sewage systems } & $\begin{array}{l}\text { preservation of } \\
\text { environment from harmful } \\
\text { effects (noise and vibration } \\
\text { levels, chemical pollution, } \\
\text { etc.) of the object }\end{array}$ & $\begin{array}{l}\text { improving the living } \\
\text { conditions of the population }\end{array}$ \\
\hline Sanitary control zone & \multicolumn{2}{|c|}{$\begin{array}{l}\text { sources and objects of } \\
\text { centralized water } \\
\text { supply }\end{array}$} & $\begin{array}{l}\text { preservation of the } \\
\text { protected object and } \\
\text { ensuring of water quality }\end{array}$ & $\begin{array}{l}\text { saving the health of the } \\
\text { population }\end{array}$ \\
\hline \multicolumn{5}{|c|}{ 2.3 Limitations around objects of industrial objects } \\
\hline $\begin{array}{l}\text { Sanitary security } \\
\text { zone }\end{array}$ & \multicolumn{2}{|c|}{ industrial objects } & $\begin{array}{l}\text { preservation of } \\
\text { environment from harmful } \\
\text { effects (noise and vibration } \\
\text { levels, chemical pollution, } \\
\text { etc.) of the object }\end{array}$ & $\begin{array}{l}\text { improving the living } \\
\text { conditions of the population }\end{array}$ \\
\hline \multicolumn{5}{|c|}{ 3. Limitations around natural objects } \\
\hline $\begin{array}{l}\text { Water conservation } \\
\text { zone }\end{array}$ & \multicolumn{2}{|c|}{$\begin{array}{l}\text { water objects (lake, } \\
\text { river, sea) }\end{array}$} & $\begin{array}{l}\text { saving the quality of water } \\
\text { resourses and preservation } \\
\text { of protected object which } \\
\text { have significant influence } \\
\text { on ecological conditions }\end{array}$ & $\begin{array}{l}\text { preserving the integrity of } \\
\text { object to ensure the social life } \\
\text { conditions (rest, studying, } \\
\text { recovering, communication). }\end{array}$ \\
\hline
\end{tabular}

* There were 7 UNESCO World Heritage Objects in Ukraine as of 2017. One of them - the Carpathian beech forests - is exclusively of natural origin. Therefore, the environmental component is taken into account (Ukraine UNESCO World Heritage Centre, 2020).

Studies of the economic effect of the formation of various zones of land use restrictions indicate a potential decreasing in the value of land and land plots that fall within the scope of restriction and and as a consequence may reduce their investment attractiveness in most cases. 
As a result of analysing scientific publications by practitioners and researchers, we can identify the following features of limitations impact assessment process:

1. It is assessed the potential impact in the future - at the stage of development of spatial plans and social programs, taking into account alternative possible options for the arrangement of mode-forming objects. 2. It is assessed the existing impact of mode-forming objects on the natural and anthropogenic environment.

In the first case, it is possible to avoid negative consequences and achieve the highest possible balance between three components of sustainable development. In this case, decisions are made under the conditions of multifaceted information support and methodological basis for making management decisions regarding restrictions.

When planning for the placement of objects, economic impact, which cannot be taken into account when assessing the impact of existing objects, shall be taken into account. Therefore, it is necessary to assess the impact on the economic situation at the planning stage.

In the second case, some environmental, social and economical conditions are already existing but appeared negative consequences have to be reduced. And in this case, achieving a balance is very difficult task and in practice usually preference is giving one of the component sustainable development. The problem of finding a balance in measuring "impact" is an urgent one, especially when it comes to land resources.

\section{Conclusions and proposals}

1. The study of mode-forming objects illustrates their fundamental difference. By origin, they can be natural, artificial and natural- artificial objects. Wherein there are legally defined mode-forming objects and objects that become mode-forming only after a correspondent official status is established.

2. Land use limitations is imposed by establishing the difference zones - protection zones, sanitary control areas, sanitary security zones, water conservation zone and special use areas. The difference in these zones is that they can protect the object, the environment around the protected object, or both. The establishment of various types of zones is aimed at providing an environmental effect, as a result of which a positive social effect - improved living conditions of the population - is achieved.

3. The greatest possible balance between the components of sustainable development under setting of land use limitations can be achieved in assessing of the potential impact in the future their consequences when developing spatial plans and social programs.

\section{References}

1. Barrow, C.J. (2002). Evaluating the Social Impacts of Environmental Change and the Environmental Impacts of Social Change: An Introductory Review of Social Impact Assessment. Environmental Studies 59(2002):2, 185-195.

2. Burdge, R. J. (1990) The Social Impact Assessment Model and the Planning Process, in: Impact Assessment Bulletin 8(1990):1\&2, pp. 85-99.

3. Dietz T. (1987) Theory and Method in Social Impact Assessment, in: Sociological Inquiry 57: 55-69.

4. Garrett Power, Constitutional Limitations on Land Use Controls, Environmental Regulations and Governmental Exactions (2013) U of Maryland Legal Studies Research Paper No. 2013-15

5. I. Trevogo, V. Ryabchiy, M Tregub, Yu Tregub (2019) Про встановлення меж охоронних зон режимоутворюючих об'єктів (About establishment of borders of protection zones of mode-forming objects) GEOFORUM'2019: abstracts of the 24th International Scientific and Technical Conference, pp. 19-20 (in Ukrainian)

6. Land Use Restrictions as Barriers to Entry (2008) the Competition Committee (Working Party No. 2 on Competition and Regulation)

7. Petrakovska O. (2010). Restrictions of urban land use in Ukraine. FIG Congress 2010, Facing the Challenges - Building the Capacity Sydney, Australia, 11-16 April 2010 Viewed 2 April, 2020, (https://www.fig.net/resources/proceedings/fig_proceedings/fig2010/papers/ts06e/ts06e_petrakovska_4491. pdf)

8. Petrakovska O. and Mykhalova M. (2018). Socio-economic and ecological aspects of land management in cities, ACTA Scientiarum Polonorum, Formatio Circumiectus Zeszyt 17 (4) 2018 pp. 103-109.

9. Sairinen, R. (2004) Assessing social impacts of urban land-use plans: From theory to practice, in: Boreal Environment Research 9(2004): 6, 509-517.

10. Ukraine - UNESCO World Heritage Centre (2020). Viewed 2 April, 2020, (https://whc.unesco.org/en/statesparties/ua)

11. Wathern. P. (1988) An introductory guide to EIA, in: Wathern P. (Ed.) Environmental Impact Assessment. Unwun HYman Ltd, London. 
12. Закон України «Про державний земельний кадастр» (Law of Ukraine «On the land cadastre») (2011). 07.07.2011 No. 3613-VI Viewed 2 April, 2020, (https://zakon.rada.gov.ua/laws/show/3613-17 ) (in Ukrainian)

13. Закон України «Про землеустрій» (Law of Ukraine «On the land management») (2003). 22.05.2003 No. 858-15 Viewed 2 April, 2020, (http://zakon3.rada.gov.ua/laws/show/2768-14 ) (in Ukrainian)

14. Закон України «Про регулювання містобудівної діяльності» (Law of Ukraine «On the regulation of spatial planning activities») (2011). 17.02.2011 No. 3038-VI Viewed 2 April, 2020, (http://zakon2.rada.gov.ua/laws/show/3038-17 ) (in Ukrainian)

15. Земельний Кодекс України (Land Code of Ukraine) (2001). 25.10.2001 No. 2767-III Viewed 2 April, 2020 , (http://zakon5.rada.gov.ua/laws/show/858-15 ) (in Ukrainian)

Information about authors:

Olga Petrakovska, Doctor of Technical Sciences, Professor, Head of Land Management and Cadastre Department, Kyiv National University of Construction and Architecture. Address: 31 Povitroflotskyi avenue, Kyiv, 03037, Ukraine, +38 06744698 62, petrakovska.os@knuba.edu.ua. Fields of interest: legal, economic, planning and technological methods of land management of urban areas; land use restrictions and spatial development of territories.

Mariia Mykhalova, PhD, Assoc. Prof, Assoc. Prof of Land Management and Cadastre Department Kyiv National University of Construction and Architecture. Address: 31 Povitroflotskyi avenue, Kyiv, 03037, Ukraine, +38 097 67966 44, mykhalova.myu@knuba.edu.ua. Fields of interest: compulsory purchase of privately owned land; land use restrictions and spatial development of territories. 